\title{
CORRIGENDUM
}

\section{Language learner perspectives on the functionality and use of electronic language dictionaries - CORRIGENDUM}

\author{
MIKE LEVY and CAROLINE STEEL
}

doi:10.1017/S095834401400038X, published by Cambrige Universtiy Press $5^{\text {th }}$ January 2015

The authors would like to amend two incorrect attributions. The authors are deeply sorry about their error.

The first attribution to be corrected is in the first sentence after the heading ' 2 Language dictionaries: Perspectives on use and design'. The sentence currently reads, "Granger (2012a: 343) states that 'many of the material issues in dictionary design are relatively form-independent'." This should be changed to "Lew (2012: 343) states that..." The end reference should also be changed from,

Granger, S. (2012a) How can we make electronic dictionaries more effective? In: Granger, S. and Paquot, M. (eds.), Electronic Lexicography. Oxford: Oxford Scholarship Online, 343-362,

to,

Lew, R. (2012). How can we make electronic dictionaries more effective? In: Granger, S. and Paquot, M. (eds.), Electronic Lexicography. Oxford: Oxford University Press, 343-361.

The second attribution to be corrected is in the second sentence of the sixth paragraph following the heading '2.2 Functionality', which reads "In a large-scale survey on dictionary use, Granger (2012b: 445, 448) found that..." This sentence should be changed to, "In a largescale survey on dictionary use, Müller-Spitzer, Koplenig and Töpel (2012: 445, 448) found that..." The end reference should also be changed from,

Granger, S. (2012b) Online dictionary use: Key findings from an empirical research project. In: Granger, S. and Paquot, M. (eds.), Electronic Lexicography. Oxford: Oxford Scholarship Online, 426-457, 
to,

Müller-Spitzer, C., Koplenig, A. and Töpel, A. (2012) Online dictionary use: Key findings from an empirical research project. In: Granger, S. and Paquot, M. (eds.), Electronic Lexicography. Oxford: Oxford University Press, 425-457.

\section{Reference}

Levy, M. and Steel, C. Language learner perspectives on the functionality and use of electronic language dictionaries, ReCALL, published online $5^{\text {th }}$ January 2015, doi:10.1017/S095834401400038X. 